\title{
Ordovician Point Pleasant/Utica-Lower Paleozoic Total Petroleum System-Revisions to the Utica- Lower Paleozoic Total Petroleum System in the Appalachian Basin Province
}

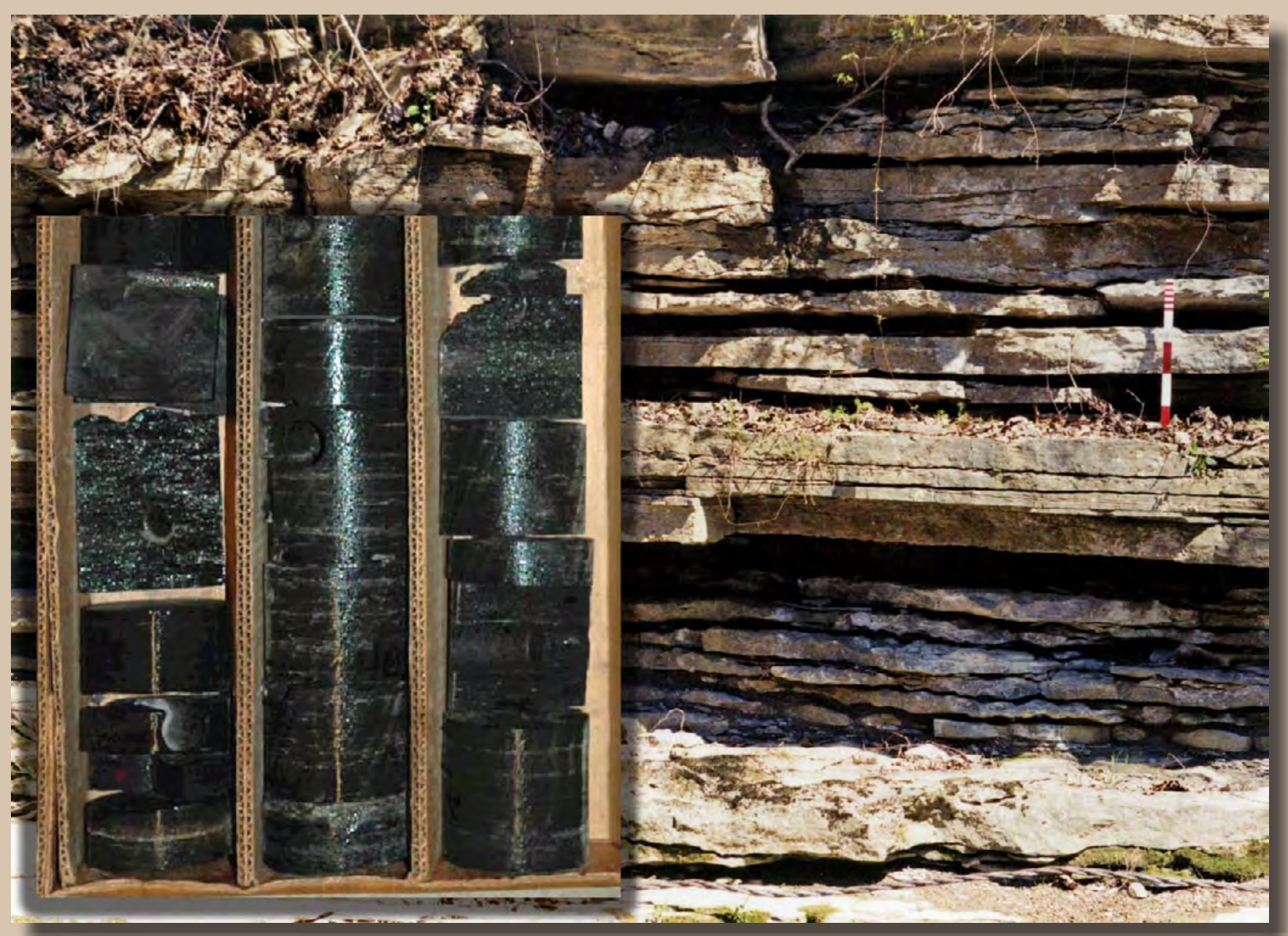

Scientific Investigations Report 2019-5025 
Cover. An outcrop of planar- to irregular-bedded limestone and shale of the Point Pleasant Formation that is exposed along Big Run in Clermont County, Ohio. The red and white measuring stick is approximately 0.5 meters in length (1.6 feet). Permission was required prior to entering private property to visit this exposure. Photograph from Schumacher and others (2013).

Inset photograph. Well core no. 3003 (API no. 3403122838) from the Point Pleasant Formation, Coshocton County, Ohio (interval depth, 5,660-5,670 feet). Total length of core shown is approximately 3 feet. Photograph provided by Michael Solis, Ohio Department of Natural Resources, Division of Geological Survey. 


\section{Ordovician Point Pleasant/Utica-Lower Paleozoic Total Petroleum System- Revisions to the Utica-Lower Paleozoic Total Petroleum System in the Appalachian Basin Province}

By Catherine B. Enomoto, Michael H. Trippi, and Debra K. Higley

Scientific Investigations Report 2019-5025 


\title{
U.S. Department of the Interior \\ DAVID BERNHARDT, Secretary
}

\author{
U.S. Geological Survey \\ James F. Reilly II, Director
}

U.S. Geological Survey, Reston, Virginia: 2019

For more information on the USGS - the Federal source for science about the Earth, its natural and living resources, natural hazards, and the environment-visit https://www.usgs.gov or call 1-888-ASK-USGS (1-888-275-8747).

For an overview of USGS information products, including maps, imagery, and publications,

visit https://store.usgs.gov.

Any use of trade, firm, or product names is for descriptive purposes only and does not imply endorsement by the U.S. Government.

Although this information product, for the most part, is in the public domain, it also may contain copyrighted materials as noted in the text. Permission to reproduce copyrighted items must be secured from the copyright owner.

Suggested citation:

Enomoto, C.B., Trippi, M.H., and Higley, D.K., 2019, Ordovician Point Pleasant/Utica-Lower Paleozoic Total Petroleum System - Revisions to the Utica-Lower Paleozoic Total Petroleum System in the Appalachian Basin Province:

U.S. Geological Survey Scientific Investigations Report 2019-5025, 6 p., https://doi.org/10.3133/sir20195025.

ISSN 2328-0328 (online) 


\section{Contents}

Abstract
Introduction
Discussion and Revision
Conclusion
Acknowledgments
References Cited

\section{Figures}

[Figure 2 is provided at https://doi.org/10.3133/sir20195025]

1. Map showing the original boundary of the Utica-Lower Paleozoic Total Petroleum System, and the extent of the newly revised Ordovician Point Pleasant/Utica-Lower Paleozoic Total Petroleum System as described in this report .....

2. Correlation chart of the stratigraphic units in the Ordovician Point Pleasant/UticaLower Paleozoic Total Petroleum System See note above 



\title{
Ordovician Point Pleasant/Utica-Lower Paleozoic Total Petroleum System-Revisions to the Utica- Lower Paleozoic Total Petroleum System in the Appalachian Basin Province
}

\author{
By Catherine B. Enomoto, Michael H. Trippi, and Debra K. Higley
}

\section{Abstract}

Hydrocarbon reserves and technically recoverable undiscovered resources in continuous accumulations are present in Upper Ordovician strata in the Appalachian Basin Province. The province includes parts of New York, Pennsylvania, Ohio, Maryland, West Virginia, Virginia, Kentucky, Tennessee, Georgia, and Alabama. The Upper Ordovician strata are part of the previously defined UticaLower Paleozoic Total Petroleum System (TPS) that extends from New York and southern Canada to Tennessee. This publication presents a revision to the hydrocarbon source rocks in the TPS, a change to the name of the TPS, and changes to the geographic extent of the Utica-Lower Paleozoic TPS. The revision to the TPS recognizes the Upper Ordovician Point Pleasant Formation as a major hydrocarbon source rock in this TPS. Consequently, the name of the TPS is changed to Ordovician Point Pleasant/Utica-Lower Paleozoic TPS. The most significant modification to the boundary of the newly defined Ordovician Point Pleasant/Utica-Lower Paleozoic TPS is a westward extension in the southwesterly portion of the TPS, adding areas in Ohio, Indiana, Kentucky, and Tennessee in order to include Ordovician strata, including potential petroleum source rocks, from the subsurface to their nearsurface exposure. Also, portions of the former Utica-Lower Paleozoic TPS are now excluded from the newly defined TPS in a portion of northwestern Ohio and adjacent States to eliminate overlap with the Ordovician to Devonian Composite TPS in the Michigan basin.

\section{Introduction}

The U.S. Geological Survey (USGS) uses the total petroleum system (TPS) concept of Magoon and Dow (1994) to assess undiscovered oil and gas resources. As defined by Magoon and Dow (1994) and Magoon and Schmoker (2000), a TPS is a naturally occurring petroleum system that can be mapped, and consists of the geologic elements (hydrocarbon source rock, reservoir rock, seal rock, and overburden rock) and fundamental processes (generation, migration, entrapment, and preservation of hydrocarbons) as well as all genetically related petroleum seeps, shows, and accumulations (both discovered and undiscovered) whose provenance is a pod or closely related pods of active source rock. The maximum geographic extent of the TPS delineates the area beyond which no oil and gas from that source rock will be found. An assessment unit (AU) is a volume of rock within the TPS that contains discovered and undiscovered petroleum accumulations that are sufficiently homogeneous in terms of geology, exploration strategy, and risk characteristics to constitute a single population of field characteristics with respect to criteria used for resource assessment. As defined by Levorsen (1967), a field is one or more pools or reservoirs of petroleum that are located on a single geologic feature or that are otherwise closely related.

The 2002 USGS assessment of undiscovered oil and gas resources of the Appalachian Basin Province (U.S. Geological Survey, 2002a, b; Milici and others, 2003) defined six TPSs. One of these TPSs was the Utica-Lower Paleozoic TPS (fig. 1), containing four conventional AUs and four continuous AUs. Two of the conventional AUs were assessed for oil, natural gas, and natural gas liquids (NGL), whereas the other two AUs were assessed for natural gas and NGL. The four continuous AUs did not have oil production at the time, and thus were assessed only for natural gas and NGL resources (Milici and others, 2003).

Ryder (2008) presented details on the stratigraphic units in the Utica-Lower Paleozoic TPS and identified the Upper Ordovician Utica Shale and thin units of black shale in the uppermost part of the Ordovician Trenton Limestone (Group) as petroleum source rocks in the TPS (see fig. 2 at https://doi.org/10.3133/sir20195025). These source rocks generated hydrocarbons that migrated into reservoirs that range in age from Late Cambrian to late Silurian (Ryder, 2008). The regional hydrocarbon seal in the Utica-Lower Paleozoic TPS was defined as the upper Silurian Salina Group, a mix of halite, anhydrite, anhydritic dolomite mudstone, 

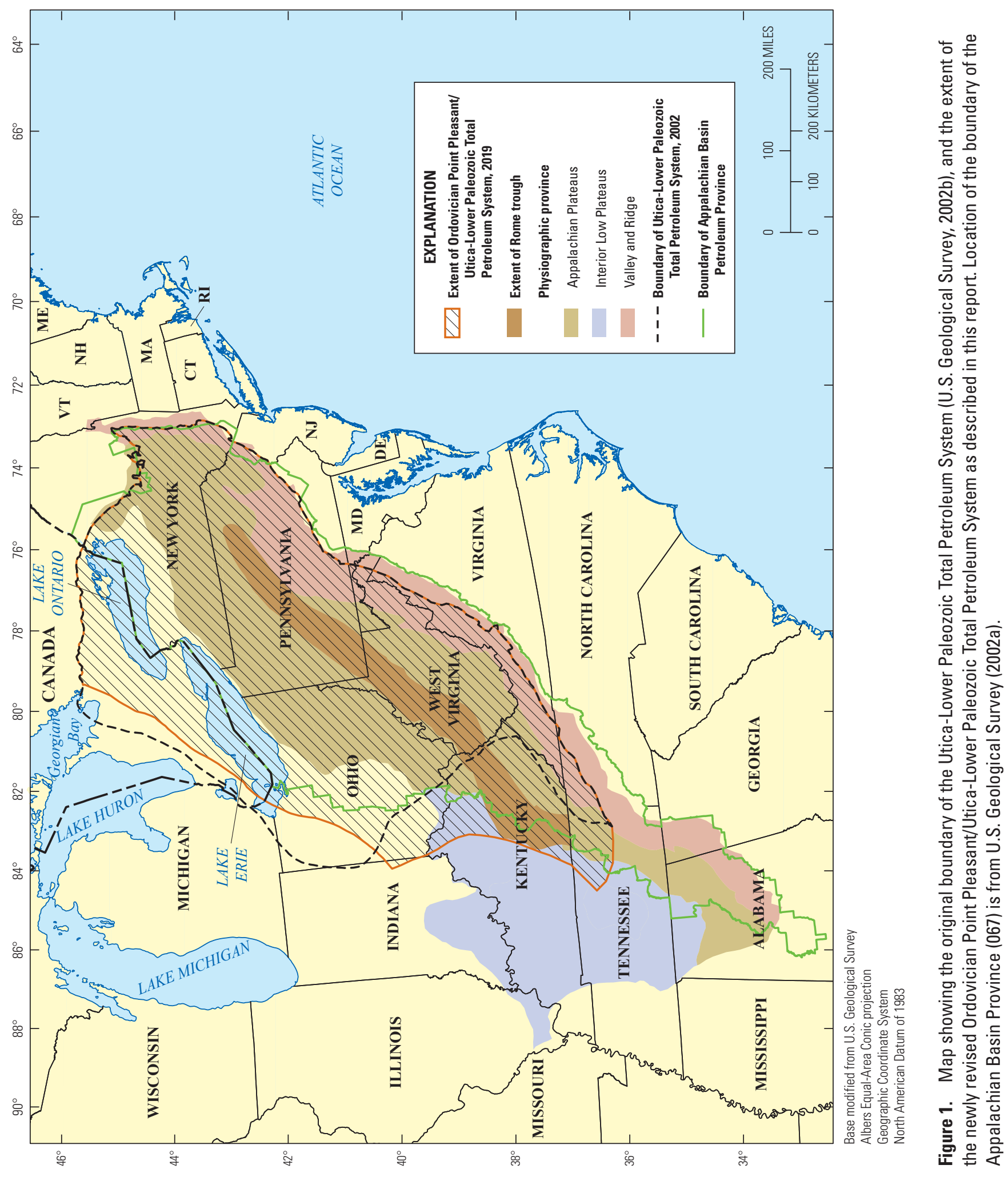
and dolomite mudstone. Secondary sealing rocks in the TPS included the Upper Ordovician Utica Shale, Reedsville Shale, Queenston Shale, and Juniata Formation, and the lower Silurian Rose Hill Formation and Rochester Shale.

More recently, following viable Utica Shale oil discoveries in the Appalachian basin, continuous oil, natural gas, and NGL resources in the Ordovician Utica Shale and Point Pleasant Formation were first assessed by Kirschbaum and others (2012).

\section{Discussion and Revision}

Several data suggest that the Ordovician Point Pleasant Formation is equal or greater in importance to the Utica Shale as a hydrocarbon source rock unit in the revised Ordovician Point Pleasant/Utica-Lower Paleozoic TPS. The Point Pleasant Formation is an interbedded limestone and organic-rich shale interval that overlies the carbonate-rich Trenton Limestone, and underlies the Utica Shale, which is shale but not necessarily more organic-rich than the Point Pleasant (Patchen and Carter, 2015). The Point Pleasant Formation was mapped in the subsurface from southern New York to the Kentucky/ Tennessee line (Hickman and others, 2015). The type section for the Point Pleasant is the town of Point Pleasant in the Ohio River Valley in Clermont County, Ohio (Orton, 1873).

The Logana Member of the Lexington Limestone in Kentucky and Ohio is an argillaceous limestone that contains approximately 70 percent carbonate and averages total organic carbon (TOC) of 4 to 5 weight percent (Patchen and Carter, 2015). The Logana Member was correlated in the subsurface to the Flat Creek Shale of New York by Hickman and others (2015). These correlative strata were mapped in the subsurface from central New York to the Kentucky/Tennessee line (Hickman and others, 2015). The type section for the Logana Member is Logana Station (now abandoned) on the Louisville and Atlantic Railroad in Jessamine County, Kentucky (Miller, 1905).

Several previous studies have discussed the possibility of the Point Pleasant Formation being a petroleum source rock. Cole and others (1987) analyzed 1,233 samples from 31 stratigraphic units and 47 reservoir oil samples from 12 stratigraphic units in Ohio and identified the Ordovician Point Pleasant Formation as a good- to excellent-quality hydrocarbon source rock. Wickstrom and others (1992) and Wickstrom (1996) suggested that the Point Pleasant Formation was the likely hydrocarbon source rock for Trenton Limestone reservoirs in Ohio. More recently, a multi-State investigation of the Utica Shale and related strata in the Appalachian basin (Eble and others, 2015) reported that the maximum TOC content of samples in 368 wells in New York, Pennsylvania, Ohio, West Virginia, and Kentucky, collected from the Point Pleasant Formation was 8 weight percent, and the maximum TOC content of samples collected in the Utica Shale was 10 weight percent. Eble and others (2015) also identified the Logana Member of Lexington Limestone as a potential source rock that was not previously recognized. The Logana Member and (or) the Point Pleasant Formation may be equivalent to the thin units of black shale in the Trenton Limestone discussed by Ryder (2008). As of March 2018 (IHS Markit ${ }^{\mathrm{TM}}, 2018$ ), about 94 percent of the wells that produced hydrocarbons from the Utica Shale and Point Pleasant Formation in New York, Pennsylvania, Ohio, and West Virginia were completed in the Point Pleasant Formation. Consequently, 94 percent of the produced natural gas and 98 percent of the oil and natural gas liquids produced from these Utica Shale and Point Pleasant wells were from the Point Pleasant Formation.

This publication describes revisions to the maximum extent of the Utica-Lower Paleozoic TPS delineated in U.S. Geological Survey (2002b), and as used by Milici and others (2003) and Kirschbaum and others (2012). The newly revised boundary of the Ordovician Point Pleasant/Utica-Lower Paleozoic TPS presented herein, and the previously published boundary of the Utica-Lower Paleozoic TPS illustrated in U.S. Geological Survey (2002b) are shown in figure 1. In the modified Ordovician Point Pleasant/Utica-Lower Paleozoic TPS, the northern, northeastern, and eastern limits remain the same as shown in U.S. Geological Survey (2002b).

The most significant change to the boundary of the Ordovician Point Pleasant/Utica-Lower Paleozoic TPS is to the southwestern extent. In easternmost Indiana, southwestern Ohio, eastern Kentucky, and north-central Tennessee, the southwestern limit of the TPS was extended to create a common border with the approximately equivalent Ordovician Ancell/Maquoketa TPS of the Illinois Basin Province (Swezey and others, 2007; U.S. Geological Survey Illinois Basin Province Assessment Team, 2007). Thus, the boundary between the Ordovician Ancell/Maquoketa TPS of the Illinois Basin Province and the Ordovician Point Pleasant/Utica-Lower Paleozoic TPS of the Appalachian Basin Province is delineated by the Cincinnati arch between the Lexington dome and Nashville dome (Ryder and others, 2012). The revised southwestern TPS boundary (fig. 1) includes the locations of all the known oil- and natural gas-productive wells in the Trenton Limestone and equivalent Lexington Limestone in the Appalachian Basin Province in Kentucky, Tennessee, and southwestern Virginia (Ryder, 2008; IHS Markit ${ }^{\mathrm{TM}}$, 2018). Previously, the Trenton Limestone wells in Virginia and some Lexington Limestone wells in Kentucky were in the Utica-Lower Paleozoic TPS. Most (but not all) of the Trenton Limestone wells in Tennessee were not in any Ordovician TPS but were in the Cincinnati Arch Province (before the USGS adopted the TPS concept of Magoon and Dow (1994) to assess undiscovered oil and gas resources). Some Lexington Limestone wells in Kentucky and Trenton Limestone wells elsewhere were not included in any TPS. Some researchers have suggested that, in addition to the Upper Ordovician strata, the Devonian Chattanooga Shale may have been a source for hydrocarbons in Trenton Limestone wells in the Cumberland saddle area in Tennessee (Ryder, 1987).

The multi-State Trenton-Black River study included analyses of natural gases produced from the Lexington Limestone in eastern Kentucky and equivalent Trenton Limestone 
in southern West Virginia, and the conclusion of those analyses was that the potential source rocks of the produced gases were the Ordovician Utica Shale, Point Pleasant Formation, Trenton Limestone, Wells Creek Formation, and (or) strata within the Lower to Middle Cambrian Rome Formation (Patchen and others, 2006). In Dennen and others (2014), analyses of oils produced from the Trenton Limestone and deeper Upper Ordovician formations in southwestern Virginia and equivalent rocks in northeastern Tennessee indicated the oils were sourced from the Upper Ordovician Trenton Limestone. The associated gases had geochemical characteristics consistent with those of the oils (Dennen and others, 2014). Ryder (2008) proposed that "thin black shale units in the uppermost part of the Trenton Limestone (Group)" were the source of the hydrocarbons in Trenton Limestone reservoirs in southwestern Virginia. We interpret these black shale units to be possibly either the Point Pleasant Formation or the Logana Member of Lexington Limestone.

The northwestern extent of the Ordovician Point Pleasant/Utica-Lower Paleozoic TPS was changed in northwestern Ohio and easternmost Indiana to eliminate overlap with and create a common border with the approximately equivalent Ordovician to Devonian Composite TPS in the Michigan Basin Province (U.S. Geological Survey Michigan Basin Province Assessment Team, 2005; Swezey and others, 2005, 2015). Thus, the boundary between the Ordovician to Devonian Composite TPS of the Michigan Basin Province and the Ordovician Point Pleasant/Utica-Lower Paleozoic TPS of the Appalachian Basin Province is delineated by the Cincinnati arch and the Findlay arch (Ryder and others, 2012).

\section{Conclusion}

The recognition of the Upper Ordovician Point Pleasant Formation as a major hydrocarbon source rock justifies a significant revision to the Utica-Lower Paleozoic TPS in the Appalachian Basin Province. Analyses of rock samples and produced oils (Cole and others, 1987) documented the Ordovician Point Pleasant Formation as a good to excellent hydrocarbon source rock. Recent well log interpretations and revised stratigraphic nomenclature support reports by operators in Ohio, West Virginia, and Pennsylvania that most of the oil and natural gas production has been from the self-sourcing Point Pleasant Formation, rather than from the Utica Shale (IHS Markit ${ }^{\mathrm{TM}}, 2018$ ). Therefore, the TPS is redefined as the Ordovician Point Pleasant/Utica-Lower Paleozoic TPS.

The boundary of the TPS, originally extending from southern Canada and New York to Tennessee, has been modified. The most significant change to the maximum extent of the TPS is to the southwest, adding areas in Ohio, Indiana, Kentucky, and Tennessee in which historical oil and natural gas production from the Trenton Limestone (and equivalent Lexington Limestone) are evidence of an Upper Ordovician carbonate petroleum system (Dennen and others, 2014). In the added area, the most likely source of hydrocarbons was the "thin black shale units in the uppermost part of the Trenton Limestone (Group)" (Ryder, 2008), interpreted herein to be either the Point Pleasant Formation or the Logana Member of the Lexington Limestone. Also, portions of the former Utica-Lower Paleozoic TPS are now excluded from the newly defined TPS in a portion of northwestern Ohio and adjacent States to eliminate overlap with the Ordovician to Devonian Composite TPS in the Michigan basin.

\section{Acknowledgments}

The authors thank Christopher Swezey (USGS) and Ernie Slucher (USGS) for their reviews of this manuscript. The authors also appreciate consultations with Robert Ryder (USGS, retired).

\section{References Cited}

Baird, G.C., and Brett, C.E., 2002, Indian Castle Shale-Late synorogenic siliciclastic succession in an evolving Middle to Late Ordovician foreland basin, eastern New York State: Physics and Chemistry of the Earth, v. 27, nos. 1-3, p. 203-230, accessed October 2018, at https://doi.org/10.1016/S1474-7065(01)00008-0.

Brett, C.E., and Baird, G.C., 2002, Revised stratigraphy of the Trenton Group in its type area, central New York StateSedimentology and tectonics of a Middle Ordovician shelf-to-basin succession: Physics and Chemistry of the Earth, v. 27, nos. 1-3, p. 231-263, accessed October 2018, at https://doi.org/10.1016/S1474-7065(01)00007-9.

Cole, G.A., Drozd, R.J., Sedivy, R.A., and Halpern, H.I, 1987, Organic geochemistry and oil-source correlations, Paleozoic of Ohio: American Association of Petroleum Geologists Bulletin, v. 71, no. 7, p. 788-809, accessed July 2018, at http://archives.datapages.com/data/bulletns/1986-87/data/ pg/0071/0007/0750/0788.htm.

Dennen, K.O., Deering, M., and Burruss, R.C., 2014, The geochemistry of oils and gases from the Cumberland overthrust sheet in Virginia and Tennessee, chap. G.12 of Ruppert, L.F., and Ryder, R.T., eds., Coal and petroleum resources in the Appalachian basin-Distribution, geologic framework, and geochemical character: U.S. Geological Survey Professional Paper 1708, 38 p., accessed September 2018, at https://doi.org/10.3133/pp1708G.12.

Eble, C.F., Hickman, J.B., Harris, D.C., and Cooney, M.L., 2015, Source rock geochemistry, in Patchen, D.G., and Carter, K.M., eds., A geologic play book for Utica Shale Appalachian basin exploration-Final report of the Utica Shale Appalachian basin exploration consortium, p. 102-141, accessed July 2018, at http:/www.wvgs.wvnet.edu/utica/ playbook/docs/FINAL_UTICA_REPORT_07012015.pdf. 
Hickman, J.B., Eble, C.F., and Harris, D.C., 2015, Subsurface mapping and correlation through geophysical log analysis, in Patchen, D.G., and Carter, K.M., eds., A geologic play book for Utica Shale Appalachian basin exploration-Final report of the Utica Shale Appalachian basin exploration consortium, p. 22-35, accessed July 2018, at http://www.wvgs.wvnet.edu/utica/playbook/docs/FINAL UTICA_REPORT_07012015.pdf.

IHS Markit ${ }^{\mathrm{TM}}$, 2018, IHS energy production data on CDROM: Englewood, Colo., IHS Markit ${ }^{\mathrm{TM}}$, database accessed March 2018, at https://my.ihs.com/Energy. [Database also available from IHS Markit ${ }^{\mathrm{TM}}, 15$ Inverness Way East, Englewood, CO 80112.]

Kirschbaum, M.A., Schenk, C.J., Cook, T.A., Ryder, R.T., Charpentier, R.R., Klett, T.R., Gaswirth, S.B., Tennyson, M.E., and Whidden, K.J., 2012, Assessment of undiscovered oil and gas resources of the Ordovician Utica Shale of the Appalachian Basin Province, 2012: U.S. Geological Survey Fact Sheet 2012-3116, 6 p. [Also available at https://pubs.usgs.gov/fs/2012/3116/.]

Levorsen, A.I., 1967, Geology of petroleum, 2d ed.: San Francisco, Calif., W.H. Freeman and Co., 724 p.

Magoon, L.B., and Dow, W.G., 1994, The petroleum system, chap. 1, in Magoon, L.B., and Dow, W.G., eds., The petroleum system-From source to trap: American Association of Petroleum Geologists Memoir 60, p. 3-24, accessed July 2018, at https://pubs.geoscienceworld.org/books/ book/1319/the-petroleum-system-from-source-to-trap.

Magoon, L.B., and Schmoker, J.W., 2000, The Total Petroleum System - The natural fluid network that constrains the assessment unit, chap. PS, in USGS World Energy Assessment Team, U.S. Geological Survey World Petroleum Assessment 2000-Description and results: U.S. Geological Survey Digital Data Series DDS-60, 31 p., accessed July 2018, at http://certmapper.cr.usgs.gov/data/PubArchives/WEcont/ chaps/PS.pdf.

Milici, R.C., Ryder, R.T., Swezey, C.S., Charpentier, R.R., Cook, T.A., Crovelli, R.A., Klett, T.R., Pollastro, R.M., and Schenk, C.J., 2003, Assessment of undiscovered oil and gas resources of the Appalachian Basin Province, 2002: U.S. Geological Survey Fact Sheet FS-009-03, 2 p. [Also available at http://pubs.usgs.gov/fs/fs-009-03/.]

Miller, A.M., 1905, The lead and zinc bearing rocks of central Kentucky, with notes on the mineral veins: Kentucky Geological Survey Bulletin, no. 2, 35 p.

Orton, E., 1873, Geology of the Cincinnati group, in Report of the Geological Survey of Ohio-Part I, Geology: Ohio Division of Geological Survey Report of Progress, 2d series, v. 1, p. 365-480.
Patchen, D.G., and Carter, K.M., eds., 2015, A geologic play book for Utica Shale Appalachian basin explorationFinal Report, April 1, 2012 [to] July 1, 2015: Utica Shale Appalachian Basin Exploration Consortium, coordinated by the Appalachian Oil \& Natural Gas Research Consortium at West Virginia University, 187 p., accessed July 2018, at http://www.wvgs.wvnet.edu/utica/playbook/ docs/FINAL_UTICA_REPORT_07012015.pdf.

Patchen, D.G., Hickman, J.B., Harris, D.C., Drahovzal, J.A., Lake, P.D., Smith, L.B., Nyahay, R., Schulze, R., Riley, R.A., Baranoski, M.T., Wickstrom, L.H., Laughrey, C.D., Kostelnik, J., Harper, J.A., Avary, K.L., Bocan, J., Hohn, M.E., and McDowell, R., 2006, A geologic play book for Trenton-Black River Appalachian basin exploration: Appalachian Oil \& Natural Gas Research Consortium at West Virginia University, U.S. Department of Energy, Final Report, Contract No. DE-FC26-03NT41856, 582 p., accessed July 2018, at http://www.wvgs.wvnet.edu/www/tbr/.

Repetski, J.E., Ryder, R.T., Weary, D.J., Harris, A.G., and Trippi, M.H., 2008, Thermal maturity patterns (CAI and $\% \mathrm{R}_{\mathrm{o}}$ ) in Upper Ordovician and Devonian rocks of the Appalachian basin-A major revision of USGS Map I-917-E using new subsurface collections: U.S. Geological Survey Scientific Investigations Map 3006, 9 sheets [8 maps and 1 correlation chart], 26-p. pamphlet, one CD-ROM. [Also available at https://pubs.usgs.gov/sim/3006/.]

Ryder, R.T., 1987, Oil and gas resources of the Cincinnati Arch, Ohio, Indiana, Kentucky, and Tennessee: U.S. Geological Survey Open-File Report 87-450-Y, 30 p., accessed July 2018, at https://doi.org/10.3133/ofr87450Y.

Ryder, R.T., 2008, Assessment of Appalachian basin oil and gas resources-Utica-Lower Paleozoic Total Petroleum System: U.S. Geological Survey Open-File Report 2008-1287, 52 p. [Also available at https://pubs.usgs.gov/ of $/ 2008 / 1287 /$.

Ryder, R.T., Swezey, C.S., Crangle, R.D., Jr., and Trippi, M.T., 2008, Geologic cross section $E-E^{\prime}$ through the Appalachian basin from the Findlay arch, Wood County, Ohio, to the Valley and Ridge Province, Pendleton County, West Virginia: U.S. Geological Survey Scientific Investigations Map 2985, 2 sheets, 48-p. pamphlet. [Also available at https://pubs.usgs.gov/sim/2985/.]

Ryder, R.T., Trippi, M.T., Swezey, C.S., Crangle, R.D., Jr., Hope, R.S., Rowan, E.L., and Lentz, E.E., 2012, Geologic cross section $C-C^{\prime}$ through the Appalachian basin from Erie County, north-central Ohio, to the Valley and Ridge Province, Bedford County, south-central Pennsylvania: U.S. Geological Survey Scientific Investigations Map 3172, 2 sheets, 70-p. pamphlet. [Also available at https://pubs.usgs.gov/sim/3172/.] 
Schumacher, G.A., Mott, B.E., and Angle, M.P., 2013, Ohio’s geology in core and outcrop-A field guide for citizens and environmental and geotechnical investigators: Columbus, Ohio, Department of Natural Resources, Division of Geological Survey Information Circular 63, $191 \mathrm{p}$.

Swezey, C.S., Hatch, J.R., Hayba, D.O., Repetski, J.E., Charpentier, R.R., Cook, T.A., Klett, T.R., Pollastro, R.M., and Schenk, C.J., 2005, Assessment of undiscovered oil and gas resources of the U.S. portion of the Michigan basin, 2004: U.S. Geological Survey Fact Sheet 2005-3070, 2 p., accessed July 2018, at https://pubs.usgs.gov/fs/2005/3070/.

Swezey, C.S., Hatch, J.R., Brennan, S.T., East, J.A., Rowan, E.L., Repetski, J.E., Charpentier, R.R., Cook, T.A., Klett, T.R., Pollastro, R.M., and Schenk, C.J., 2007, Assessment of undiscovered oil and gas resources of the Illinois basin, 2007: U.S. Geological Survey Fact Sheet 2007-3058, 2 p., accessed July 2018, at https://pubs.usgs.gov/fs/2007/3058/.

Swezey, C.S., Hatch, J.R., East, J.A., Hayba, D.O., and Repetski, J.E., 2015, Total petroleum systems of the Michigan basin-Petroleum geology and geochemistry and assessment of undiscovered resources, chap. 2 of U.S. Geological Survey Michigan Basin Province Assessment Team, Geologic assessment of undiscovered oil and gas resources of the U.S. portion of the Michigan basin: U.S. Geological Survey Digital Data Series DDS-69-T, 162 p., accessed July 2018, at https://doi.org/10.3133/ds69T.

U.S. Geological Survey Illinois Basin Province Assessment Team, 2007, National Assessment of Oil and Gas ProjectIllinois Basin Province (064) Total Petroleum Systems: U.S. Geological Survey, spatial data accessed July 2018, at http://certmapper.cr.usgs.gov/data/noga00/prov64/spatial/ shape/tps64g.zip.
U.S. Geological Survey Michigan Basin Province Assessment Team, 2005, National Assessment of Oil and Gas ProjectMichigan Basin Province (063) Total Petroleum Systems: U.S. Geological Survey, spatial data accessed July 2018, at http://certmapper.cr.usgs.gov/data/noga00/prov63/spatial/ shape/tps63g.zip.

U.S. Geological Survey, 2002a, National Assessment of Oil and Gas Project-Appalachian Basin Province (067) boundary: U.S. Geological Survey, spatial data accessed July 2018, at http://certmapper.cr.usgs.gov/data/noga00/prov67/ spatial/shape/pr67bndg.zip.

U.S. Geological Survey, 2002b, National Assessment of Oil and Gas Project-Appalachian Basin Province (067) Total Petroleum Systems, Utica-Lower Paleozoic (506703): U.S. Geological Survey, spatial data accessed July 2018, at http://certmapper.cr.usgs.gov/data/noga00/prov67/spatial/ shape/tps6703g.zip.

Wickstrom, L.H., Gray, J.D., and Stieglitz, R.D., 1992, Stratigraphy, structure, and production history of the Trenton Limestone (Ordovician) and adjacent strata in northwestern Ohio: Ohio Division of Geological Survey Report of Investigations No. 143, 78 p., 1 pl., accessed July 2018, at https://kb.osu.edu/handle/1811/80253.

Wickstrom, L.H., 1996, Play MOf-Middle Ordovician fractured carbonates, in Roen, J.B., and Walker, B.J., eds., The atlas of major Appalachian gas plays: West Virginia Geologic and Economic Survey Publication V-25, p. 172-176. [Also available at http://www.wvgs.wvnet.edu/wvges2/publications/PubCat_Details.aspx?PubCatID=V-25.] 
Manuscript approved April 1, 2019

Publishing support provided by the U.S. Geological Survey

Science Publishing Network, Reston Publishing Service Center

Edited by David A. Shields

Layout by Jeffrey Corbett

For more information concerning this report, contact:

Director, Eastern Energy Resources Science Center

U.S. Geological Survey

956 National Center

Reston, VA 20192

http://energy.usgs.gov/

http://energy.usgs.gov/Generallnfo/ScienceCenters/Eastern.aspx 


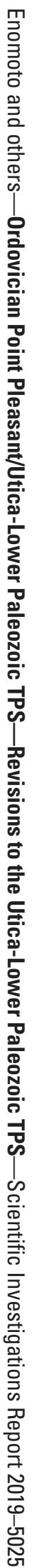

